\title{
Prepare to succeed, panic to fail: The mantra for COVID-19 prevention in India
}

\author{
Shivashankar Kengadaran ${ }^{1}$, Anusha Divvi ${ }^{1}$, Sivabalakumaran Kengadaran ${ }^{2}$
}

\section{AFFILIATION}

1 Department of Public Heath Dentistry, Indira Gandhi Institute of Dental Sciences, Sri Balaji Vidyapeeth, Pondicherry, India

2 Department of Anaesthesiology, Government Chengalpattu Medical College, Chengalpattu, India

\section{CORRESPONDENCE TO}

Shivashankar Kengadaran. Department of Public Heath Dentistry, Indira Gandhi Institute of Dental Sciences, Sri Balaji Vidyapeeth, Pondicherry, 607402, India. E-mail: shiva.freee@gmail.com ORCID ID: https://orcid. org/0000-0002-6868-9639

Popul. Med. 2020;2(April):7
KEYWORDS

coronavirus, COVID-19, novel virus, pandemic, epidemic

Received: 19 March 2020, Accepted: 5 April 2020

\section{Dear Editor,}

Epidemics or pandemics caused by emerging and reemerging infections take a heavy toll on life and can cause much distress and panic by rapidly spreading across borders ${ }^{1}$. Recently, in December 2019, there was an epidemic outbreak of a novel coronavirus (COVID-19) in Wuhan, China, that has now been proclaimed a pandemic by the World Health Organization. The infected subjects present with respiratory symptoms including fever, cough, and shortness of breath. Severe cases present with symptoms of pneumonia and severe acute respiratory syndrome, and some result in death $^{2}$. Many aspects of disease progression have been noted including the existence of comorbidities and tobacco use $\mathrm{e}^{3,4}$.

The first case of COVID-19 in India was reported on 30 January 2020, originating from China. To date, around 151 cases have been identified of which 3 cases resulted in death ${ }^{5}$. The Indian Council of Medical Research has categorized the spread of disease into four stages: 1) Imported cases (infected cases traveling from other countries); 2) Local spread (infected persons contacting one or two persons); 3) Community spread; and 4) Epidemic outbreak 6 .

India is currently in stage 2 , and, especially with its very large population, surveillance will become nearly impossible if the disease progresses to stage 35 . Hence, preventive measures were timely taken by the government including: shutting down of tourist areas, religious places, shopping malls, cinema theatres and the public transport system; suspension of the operation of colleges and schools, and the cancellation of conferences, sports gatherings, meetings etc.; creation of a self-reporting portal for symptomatic patients in several states; screening of subjects having a travel history to another country since January 2020; and allowing only emergency dental care.

In support of the government's strategic and proactive measures, citizens need to demonstrate equal responsibility and respond to the current situation in a positive manner. On the other hand, the spreading of rumours, hiding travel history, creating panic in society, unnecessary travel by considering the situation as a vacation, and over-reporting at hospitals and dental clinics for what are regular issues, have been observed to be the most common hindrances in tackling the pandemic.

Citizens can help the government's efforts to handle the situation by: staying indoors in a safe place; practicing social distancing; following standard public health recommendations such as frequent cleaning of hands using alcohol-based lotions or simply soap and water; covering nose and mouth with a bent elbow or disposable tissue when coughing and sneezing; maintaining self-quarantine if there are indicative symptoms; and avoiding close contact with anyone that has a fever and cough ${ }^{7}$.

The government, in turn, needs to follow a holistic approach and consider also the economic instability of and burden on the population, provide tax relaxation on essential products and relaxation on due dates for loans, provide compensation to small-scale sellers, and prevent price increases on essential goods. These measures will help the population to abide by the safety measures advised by the health organizations and will prevent physical and mental distress.

\section{REFERENCES}

1. Dikid T, Jain SK, Sharma A, Kumar A, Narain JP. Emerging \& re-emerging infections in India: an overview. Indian J Med Res. 2013;138(1):19-31. PMID:24056553. 
2. World Health Organization. Coronavirus Disease (COVID-19) Outbreak: Rights, Roles and Responsibilities of Health Workers, Including Key Considerations for Occupational Safety and Health. Geneva, Switzerland: World Health Organization; 2020. https://www.who.int/docs/defaultsource/coronaviruse/who-rights-roles-respon-hw-covid-19. pdf?sfvrsn=bcabd401_0. Accessed March 30, 2020.

3. Bonow RO, Fonarow GC, O'Gara PT, Yancy CW. Association of Coronavirus Disease 2019 (COVID-19) With Myocardial Injury and Mortality. JAMA Cardiol. 2020. doi:10.1001/jamacardio.2020.1105
4. Vardavas CI, Nikitara K. COVID-19 and smoking: A systematic review of the evidence. Tob Induc Dis. 2020;18(March):1-4. doi:10.18332/tid/119324

5. Ministry of Health and Family Welfare. COVID in India. https://www.mohfw.gov.in/. Accessed March 18, 2020.

6. Ministry of Health and Family Welfare. Stages of Corona Spread in India. www.mohfw.gov.in. Accessed March 18, 2020.

7. United States Department of Labor. Safety and Health Topics:COVID-19. https://www.osha.gov/SLTC/covid-19/ index.html. Accessed March 18, 2020.
CONFLICTS OF INTEREST

The authors have completed and submitted the ICMJE Form for Disclosure of Potential Conflicts of Interest and none was reported.
PROVENANCE AND PEER REVIEW

Not commissioned; externally peer reviewed. 